
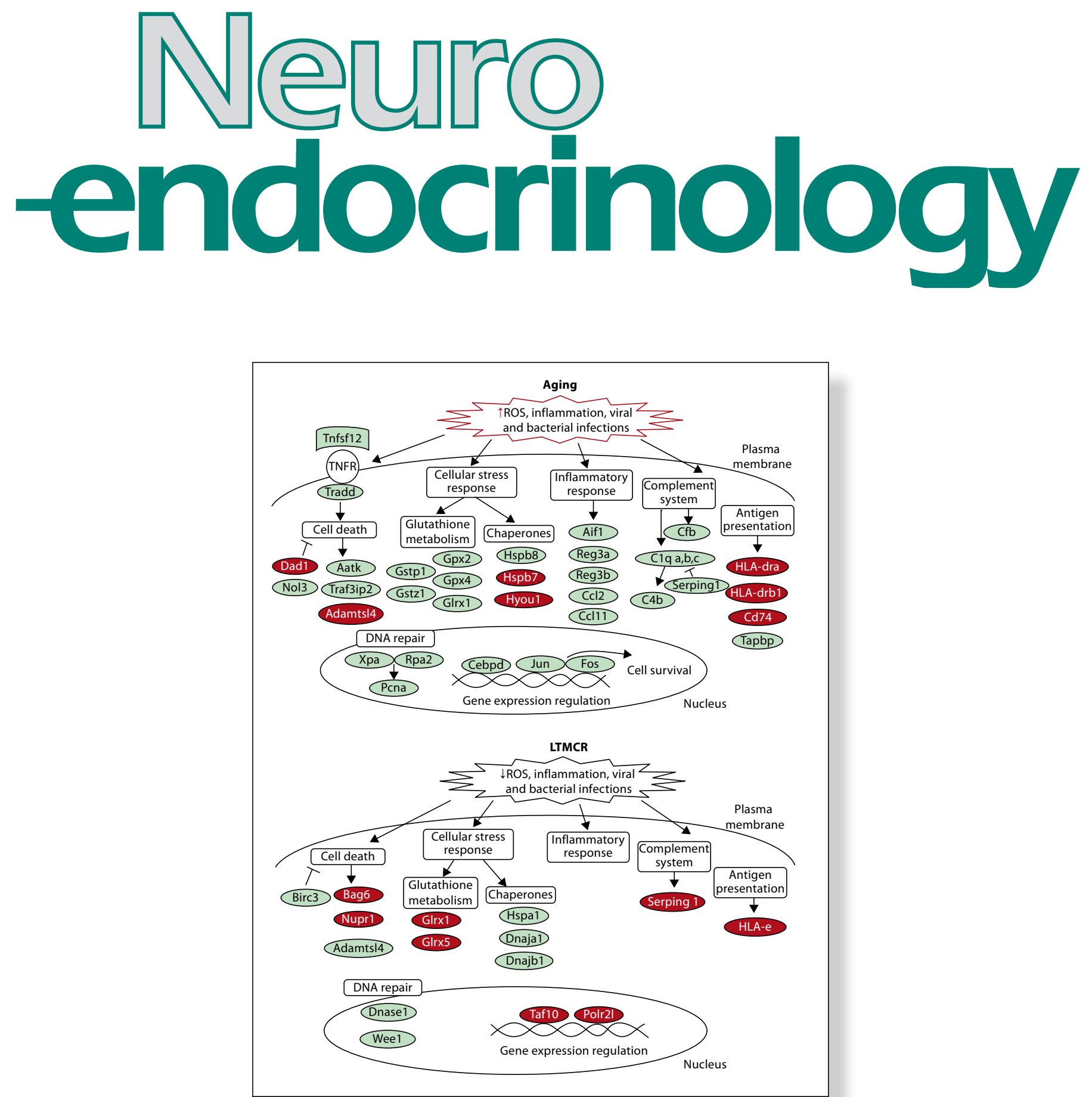

S. Karger

Medical and Scientific Publishers Basel · Freiburg · Paris .

London · New York .

New Delhi · Bangkok · Beijing ·

Tokyo - Kuala Lumpur .

Singapore - Sydney
Official Journal of

International Neuroendocrine Federation

European Neuroendocrine Association

European Neuroendocrine Tumor Society 


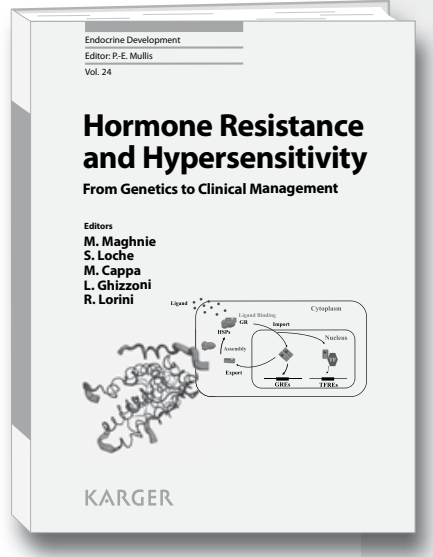

\section{Hormone Resistance and Hypersensitivity

\author{
From Genetics to Clinical Management
}

\author{
Editors \\ Mohamad Maghnie \\ Sandro Loche \\ Marco Cappa \\ Lucia Ghizzoni \\ Renata Lorini
}

Hormone Resistance and Hypersensitivity From Genetics to Clinical Management Editors: Maghnie, M. (Genoa);

Loche, S. (Cagliari); Cappa, M. (Rome);

Ghizzoni, L. (Turin); Lorini, R. (Genoa)

VIII + 160 p., 26 fig., 7 in color, 10 tab., 2013

CHF 168.- / EUR 140.- / USD 198.00 (hard cover)

CHF 202.- / EUR 168.- / USD 238.00 (online)

Online version for institutional purchase

Prices subject to change

EUR price for Germany, USD price for USA only

ISBN 978-3-318-02267-4 (hard cover)

e-ISBN 978-3-318-02268-1

Endocrine Development, Vol. 24

Series Editor: P.-E. Mullis (Bern)

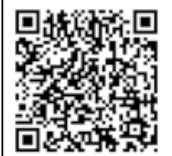

Dear Librarian

I have reviewed this publication and

would like to recommend it for our library.

Recommended by:

Department:

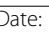

Signature:

Orders may be placed with any bookshop, subscription agency, directly with the publisher or through a Karger distributor.
Over recent years, impressive advances in genetic/ epigenetic technology have greatly improved the understanding of the pathogenesis of pediatric endocrine diseases due to hormone resistance and hypersensitivity.

This book presents reviews of thyroid hormone and thyroid hormone receptor resistance, and genetics and epigenetics of parathyroid hormone resistance. Abnormalities of the pituitary-gonadal axis affecting puberty as well as androgen receptor are covered. Novel insights into the diseases affecting ACTH, glucocorticoid and aldosterone receptors are discussed. Further chapters address new aspects of the physiology of the GH and IGF-1 axis as well as the diseases related to GH-IGF-1 receptor and post-receptor signaling defects. A key chapter on metabolic insights into insulin resistance is also included.

Covering clinical and genetic aspects of hormone resistance and hypersensitivity, this book will be a useful tool in the hands of scientists, physicians and other healthcare professionals who wish to be up to date with novel research findings in this area.

\section{Contents}

-Preface: Maghnie, M.; Loche, S.; Cappa, M.; Ghizzoni, L.; Lorini, $\mathbf{R}$.

-Thyroid Hormone Transporters and Resistance: Visser, T.J.

- Genetics and Epigenetics of Parathyroid Hormone Resistance: Bastepe, $\mathbf{M}$.

-Gonadotropin Resistance: Latronico, A.C.; Arnhold, I.J.P.

- Clinical and Molecular Aspects of Androgen Insensitivity: Hiort, 0 .

- Exploring the Molecular Mechanisms of Glucocorticoid Receptor Action from Sensitivity to Resistance: Ramamoorthy, S.; Cidlowski, J.A.

-ACTH Resistance: Genes and Mechanisms:

Meimaridou, E.; Hughes, C.R.; Kowalczyk, J.; Chan, L.F.; Clark, A.J.L.; Metherell, L.A.

-Primary Generalized Familial and Sporadic Glucocorticoid Resistance (Chrousos Syndrome) and Hypersensitivity: Charmandari, E.; Kino, T.; Chrousos, G.P.

-Pseudohypoaldosteronism: Riepe, F.G.

- New Aspects of the Physiology of the GH-IGF-1

Axis: Vottero, A.; Guzzetti, C.; Loche, S.

- Molecular and Clinical Aspects of GHRH Receptor Mutations: Corazzini, V.; Salvatori, R.

- Current Issues on Molecular Diagnosis of GH

Signaling Defects: Feigerlova, E.; Hwa, V.; Derr, M.A.; Rosenfeld, R.G.

- Molecular IGF-1 and IGF-1 Receptor Defects:

From Genetics to Clinical Management:

Walenkamp, M.J.E.; Losekoot, M.; Wit, J.M.

-Phenotypes, Investigation and Treatment of

Primary IGF-1 Deficiency: Savage, M.O.

- Human Congenital Perilipin Deficiency and Insulin

Resistance: Kozusko, K.; Patel, S.; Savage, D.B.

- Author Index

- Subject Index 
Official Journal of

\begin{tabular}{ll}
\hline & $\begin{array}{l}\text { International } \\
\text { Neuroendocrine } \\
\text { Federation (INF) }\end{array}$ \\
\hline ENETS & $\begin{array}{l}\text { European } \\
\text { Eeuroendocrine } \\
\text { Association (ENEA) }\end{array}$ \\
\hline \multirow{2}{*}{$\begin{array}{l}\text { Eeuroendocrine } \\
\text { Tumor Society (ENETS) }\end{array}$} \\
\hline
\end{tabular}

\section{Editor-in-Chief}

R.P. Millar, Edinburgh

\section{Editorial Manager}

A. Kirsop, Edinburgh

\section{Editors}

I.J. Clarke, Clayton, Vic.

C. Coen, London

M.A. Cowley, Clayton, Vic.

W.W. de Herder, Rotterdam

A. Enjalbert, Marseille

A.B. Grossman, Headington

D. Jezová, Bratislava

A.S. Kauffman, La Jolla, Calif.

M.J. Kelly, Portland, Oreg.

P.A. Kelly, Paris

S.R. Ojeda, Beaverton, Oreg. (Reviews)

G. Rindi, Rome

M. Tena-Sempere, Cordoba

B. Wiedenmann, Berlin

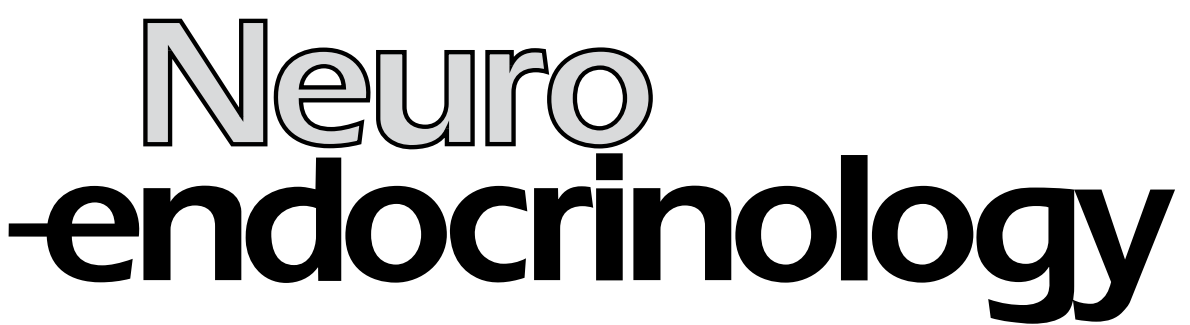

International Journal for Basic and Clinical Studies on Neuroendocrine Relationships

Founded 1965 by E. Bajusz

Continued by K.M. Knigge (1973-1978), W.F. Ganong (1979-1984),

S.M. McCann (1985-1993), C. Kordon (1994-2005)

\section{Editorial Board}

D.H. Abbott, Madison, Wisc.

E. Arzt, Buenos Aires

A.V. Babwah, London, Ont.

T. Bartness, Atlanta, Ga.

C.L. Bethea, Beaverton, Oreg.

D.W. Brann, Augusta, Ga.

B. Canny, Monash, Vic.

M. Caplin, London

K. Catt, Bethesda, Md.

A. Chodobski, Providence, R.I.

S.L. Dickson, Gothenburg

J. Drouin, Montreal, Que.

P.J. Enriori, Monash, Vic.

W. Farrell, Keele

M. Freeman, Tallahasse, Fla.

A.C. Gore, Austin, Tex.

K. Grove, Beaverton, Oreg.

T. Harmar, Edinburgh

A. Herbison, Dunedin

J. Herman, Cincinnati, Ohio

J.J. Hirst, Callaghan, N.S.W.

T. Hökfelt, Stockholm

U. Kaiser, Boston, Mass.

K. Kim, Seoul

J.Z. Kiss, Geneva

A.C. Latronico, São Paulo

G. Leng, Edinburgh

J. Levine, Evanston, Ill.

C. Libertun, Buenos Aires

C. Llorens-Cortes, Paris

A. Lomniczi, Beaverton, Oreg.

A. Loudon, Manchester

Z.-L. Lu, Edinburgh
G. Martinez de la Escalera, Querétaro

R. Melcangi, Milano

I. Modlin, New Haven, Conn.

Z. Naor, Tel Aviv

M. Palkovits, Budapest

I. Parhar, Kuala Lumpur

D.W. Pfaff, New York, N.Y.

T.M. Plant, Pittsburgh, Pa.

J. Reul, Bristol

R. Reynolds, Edinburgh

E. Rissman, Charlottesville, Va.

J.L. Roberts, San Antonio, Tex.

I. Robinson, London

P. Ruszniewski, Clichy

W. Schlegel, Geneva

D. Skinner, Laramie, Wyo.

M. Sleeman, Clayton, Vic.

J. Smith, Perth, W.A.

E. Spinedi, La Plata

R. Steiner, Seattle, Wash.

E. Terasawa, Madison, Wisc.

A. Tilbrook, Roseworthy, S.A.

E. Wagner, Pomona, Calif.

B. Walker, Edinburgh

H. Watanobe, Chiba

M. Watt, Clayton, Vic.

M. Wierman, Denver, Colo.

J. Wingfield, Seattle, Wash.

S. Wray, Bethesda, Md.
Printed in Switzerland on acid-free and non-aging paper (ISO 9706) by Reinhardt Druck, Basel
Appears 6-weekly: 2 volumes per year (8 issues) 


\section{Neura \\ endocrinology}

The Editorial Board of Neuroendocrinology welcomes articles for review that report new observations on interactions between the brain and the endocrine system. Papers that are published deal with both basic and clinical subjects. Editorials, summaries of meetings, and reviews of timely topics in basic and clinical neuroendocrinology are also published, but these items are accepted only at the invitation of the Editor-in-Chief.

\section{Submission}

Manuscripts written in English should be submitted using the online submission website at:

www.karger.com/nen

or as e-mail attachment (the preferred word-processing package is MS-Word) to the Editorial Office:

editor@nen-edinburgh.org

Editorial Office 'Neuroendocrinology'

Prof. Dr. Robert Millar

South Lodge

295 Gilmerton Road

Edinburgh EH16 5UL (UK)

Tel. +441312080769

Editorial Manager

Dr. Allison Kirsop

editor@nen-edinburgh.org

Manuscripts should contain unpublished results of research work, and should be as concise as possible. The following presentation is recommended: Abstract. Introductory statement on the purpose of the studies, Materials and methods, Results, on the purpose of the studies, Materials and methods, Results, Discussion, and References. Current abbreviations should be used throughout the text and tables (for pituitary hormones: ACTH, Th-END, FSH, GH, LH, TSH; for neuropeptides: CRH, not CRF; GAL; GHRH, not GRF; GnRH, not LHRH; NPY; NT; SRIH, not SRIF; VIP...), and a definition should be provided the first time each abbreviation appears. Please limit abbreviations to those in common use, and avoid other ab breviations and acronyms. Manuscripts should contain novel, original data. As a rule, the Editorial office commits itself to achieve initial review of manuscripts within less than 60 days; average interval between submission and publication is 7-9 months. Authors of articles reporting mostly confirmatory, fragmentary or preliminary findings may be notified within 2 weeks that their manuscript will not be submitted to formal review. Such a proposal will be made by the associate Editors assisted by one member of the Editorial Board. This procedure is intended to provide rapid feedback to authors of manuscripts which have a poor chance of being accepted. Authors have the opportunity to appeal against the decision. Contributors should know that one of the criteria considered in reviewing manuscripts is the humane and proper treatment of animals. The editors realize that the use of anesthetics, analgesics, and tranquilizers would defeat the purpose of some experiments. However, the use of painful or otherwise noxious stimuli must be carefully and thoroughly justified in the paper. Papers that do not meet these criteria will not be accepted for publication.

\section{Conditions}

All manuscripts are subject to editorial review. Manuscripts are received with the explicit understanding that they are not under simultaneous consideration by any other publication. Submission of an article for publication implies the transfer of the copyright from the author to the publisher upon acceptance. Accepted papers become the permanent property of 'Neuroendocrinology' and may not be reproduced by any means, in whole or in part, without the written consent of the publisher. It is the author's responsibility to obtain permission to reproduce illustrations, tables, etc. from other publications.

\section{Arrangement}

Title page: The first page of each paper should carry the title, the authors full first and last names, and the name of the institute or department where the authors conducted their research work. In addition, the following should be put on the title page: 1. A short title for use as a running head. 2. A list of 3-9 key words that reflect the content of the paper. 3 . The name and complete mailing address as well as phone and fax numbers and e-mail address of the individual to whom correspondence, proofs, and requests for reprints should be addressed.

Abstract: Each paper must have a short abstract describing procedures, observations and conclusions, which will appear at the beginning of the article. Abstracts should not exceed 250 words.

Footnotes: Avoid footnotes if at all possible. When essential, they should be numbered consecutively and typed at the foot of the appropriate page.

Acknowledgments: Including, where relevant, credit to the sources of grant support.

Tables and illustrations: Tables (numbered in arabic numerals) should be prepared on separate sheets, and each should have a suitable heading. Illustrations should be numbered in Arabic numerals and legends for the figures should be submitted on a separate page. For the reproduction of illustrations, only good drawings and original photographs can be accepted; negatives or photocopies cannot be used. Due to technical reasons, figures with a screen background should not be submitted. When possible, group several illustrations on one block for reproduction (max. size $180 \times 223 \mathrm{~mm}$ ) or provide crop marks. Electronically submitted b/w half-tone and color illustrations must have a final resolution of $300 \mathrm{dpi}$ after scaling, line drawings one of 800-1200 dpi.

References: In the text identify references by Arabic numerals [in square brackets]. Material submitted for publication but not yet accepted should be noted as 'unpublished data' and not be included in the reference list. The list of referenc es should include only those publications which are cited in the text. Do not alphabetize; number references in the order in which they are first mentioned in the text. The surnames of all the authors followed by initials should be given. There should be no punctuation other than a comma to separate the authors. Preferably, please cite all authors. Abbreviate journa names according to the Index Medicus system. Also see International Committee of Medical Journal Editors: Uniform requirements for manuscripts submitted to biomedical journals (www.icmje.org)

Examples:

(a) Papers published in periodicals: Sun J, Koto H, Chung KF: Interaction of ozone and allergen challenges on bronchial responsiveness and inflammation in sensitised guinea pigs. Int Arch Allergy Immunol 1997;112:191-195.

(b) Papers published only with DOI numbers:

Theoharides TC, Boucher W, Spear K: Serum interleukin-6 reflects disease severity and osteoporosis in mastocytosis patients. Int Arch Allergy Immunol DOI: 10.1159/000063858. (c) Monographs: Matthews DE, Farewell VT: Using and Understanding Medical Statistics, ed 3, revised. Basel, Karger, 1996.

(d) Edited books: Parren PWHI, Burton DR: Antibodies against HIV-1 from phage display libraries: Mapping of an mmune response and progress towards antiviral immunotherapy; in Capra JD (ed): Antibody Engineering. Chem Immunol. Basel, Karger, 1997, vol 65, pp 18-56.

Papers that have been submitted to a journal but are not yet accepted should not be listed in the bibliography, but the dat in them can be referred to in the text as unpublished observations. If details of methods are only available in papers that are 'in press', copies of the papers should be included with the manuscript submitted to 'Neuroendocrinology', so that the editorial referees can have adequate information to judge the manuscript.

Reference Management Software: Use of EndNote is recommended for easy management and formatting of citations and reference lists.
Digital Object Identifier (DOI)

S. Karger Publishers supports DOIs as unique identifiers for articles. A DOI number will be printed on the title page of each article. DOIs can be useful in the future for identifying and citing articles published online without volume or issue information. More information can be found at www.doi.org.

\section{Author's Choice ${ }^{\mathrm{TM}}$}

Karger's Author's Choice ${ }^{\mathrm{TM}}$ service broadens the reach of you article and gives all users worldwide free and full access fo reading, downloading and printing at www.karger.com. The option is available for a one-time fee of CHF 3000.-, which is a permissible cost in grant allocation. More information can be found at www.karger.com/authors_choice.

\section{NIH-Funded Research}

The U.S. National Institutes of Health (NIH) mandates under the NIH Public Access Policy that final, peer-reviewed manuscripts appear in its digital database within 12 months of the official publication date. As a service to authors, Karger submits the final version of your article on your behalf to PubMed Central. For those selecting our premium Author's Choice ${ }^{\mathrm{TM}}$ service, we will send your article immediately upon publish ing, accelerating the accessibility of your work without the usual embargo. More details on NIH's Public Access Policy is available at http://publicaccess.nih.gov/policy.htm

\section{Self-Archiving}

Karger permits authors to archive their pre-prints (i.e. prerefereeing) or post-prints (i.e. final draft post-refereeing) on their personal or institution's servers, provided the following conditions are met: Articles may not be used for commercial purposes, must be linked to the publisher's version, and must acknowledge the publisher's copyright. Authors selecting Karger's Author's Choice ${ }^{\mathrm{TM}}$ feature, however, are also permitted to archive the final, published version of their article, which includes copyediting and design improvements as well as citation links.

Proofs

Unless indicated otherwise, a PDF for correction is sent to the corresponding author and should be returned with the least possible delay. Alterations other than the correction of printer's errors are charged to the author.

\section{E-pub First}

All articles are published electronically ahead of print with a DOI number and are supplemented later with the definite reference of the printed version. The articles become available immediately after the authors" approval to publication, with the added advantage of being citable much earlier than in print. Authors can influence the time of appearance by promptly returning the proofs.

Reprints

Order forms and a price list are sent with the PDF. Order submitted after the issue is printed are subject to considerably higher prices.

\section{Supplementary Materia}

Supplementary material is restricted to additional data that are not necessary for the scientific integrity and conclusion of the paper. Please note that all supplementary files will undergo editorial review and should be submitted together with the original manuscript. The Editors reserve the right to limit the scope and length of the supplementary material Supplementary material must meet production quality standards for Web publication without the need for any modification or editing. In general, supplementary files should not exceed $10 \mathrm{MB}$ in size. All figures and tables should have titles and legends and all files should be supplied separately and named clearly. Acceptable files and formats are: Word or PDF files, Excel spreadsheets (only if the data cannot be converted properly to a PDF file), and video files (.mov, .avi, .mpeg).

\section{KARGER}

E-Mail karger@karger.com www.karger.com
(C) 2013 S. Karger AG, Basel 


\section{Neuro \\ endocrinology}

ISSN Print Edition: 0028-3835

ISSN Online Edition: 1423-0194

Journal Homepage: www.karger.com/nen

Publication Data: 'Neuroendocrinology' is published 8 times a year. Volumes 97 and 98 , each with 4 issues, appear in 2013

Copyright: (c) 2013 S. Karger AG, Basel (Switzerland). All rights reserved. No part of this publication may be translated into other languages, reproduced or utilized in any form or by any means, electronic or mechanical, including photocopying, recording, microcopying, or by any information storage and retrieval system, without permission in writing from the publisher or, in the case of photocopying, direct payment of a specified fee to the Copyright Clearance Center.

Disclaimer: The statements, opinions and data contained in this publication are solely those of the individual authors and contributors and not of the publisher and the editor(s). The appearance of advertisements in the journal is not a warranty, endorsement, or approval of the products or services advertised or of their effectiveness, quality or safety. The publisher and the editor(s) disclaim responsibility for any injury to persons or property resulting from any ideas, methods, instructions or products referred to in the content or advertisements.
Subscription Rates: Subscriptions run for a full calendar year. Prices are given per year. Personal subscription:

Print or Online

CHF 1700.-

EUR 1370.-

USD 1682.00

Print+Online combined CHF 1796.-

EUR 1448.-

USD 1778.00

postage and handling (added to print and print+online)

CHF 57.60 Europe, CHF 83.20 Overseas

EUR 44.80

USD 76.80

Institutional subscription:

Print or Online

Print+Online combined

CHF 3398.-

EUR 2740.-

CHF 3783.-

postage and handling (added to print and print+online)

CHF 72.- Europe, CHF 104.- Overseas

EUR 56.-

USD 96.00

Airmail surcharge: CHF 70.- / USD 66.00

Discount subscription prices:

Int. Neuroendocrine Federation

Europ. Neuroendocrine Association
Back Volumes and Single Issues: Information on availability and prices of single print issues and print or electronic back volumes can be obtained from Customer Service atservice@karger.com.

Bibliographic Indices: This journal is regularly listed in bibliographic services, including Current Contents ${ }^{\circledR}$ and PubMed/MEDLINE.

Photocopying: This journal has been registered with the Copyright Clearance Center (CCC), as indicated by the code appearing on the first page of each article. For readers in the US, this code signals consent for copying of articles for personal or internal use, or for the personal or internal use of specific clients, provided that the stated fee is paid per copy directly to

Copyright Clearance Center Inc.

222 Rosewood Drive

Danvers, MA 01923 (USA)

A copy of the first page of the article must accompany payment. Consent does not extend to copying for general distribution, for promotion, for creating new works, or for resale. In these cases, specific written permission must be obtained from the copyright owner,

S. Karger AG, P.O. Box

CH-4009 Basel (Switzerland).
Subscription Orders:

Orders can be placed at agencies, bookstores, directly with the Publisher

\section{S. Karger AG}

Medical and Scientific Publishers

Allschwilerstrasse 10

CH-4009 Basel

Switzerland

t: +41613061111

f: +41613061234

e: karger@karger.com

w: www.karger.com

(for courier services only:

Allschwilerstrasse 10

CH-4055 Basel)

\begin{tabular}{|c|c|}
\hline $\begin{array}{l}\text { or further Karger offices } \\
\text { or representatives: }\end{array}$ & $\begin{array}{l}\text { USA } \\
\text { S. Karger Publishers, Inc. } \\
26 \text { West Avon Road }\end{array}$ \\
\hline Germany & P.O. Box 529 \\
\hline S. Karger GmbH & Unionville, CT 06085 \\
\hline Postfach & USA \\
\hline 79095 Freiburg & Toll free: +18008285479 \\
\hline Deutschland & $\mathrm{t}: \quad+18606757834$ \\
\hline (Hausadresse: Wilhelmstrasse 20A, & f: $\quad+18606757302$ \\
\hline $\begin{array}{l}\text { 79098 Freiburg) } \\
\mathrm{t}: \quad+49761452070\end{array}$ & e: karger@snet.net \\
\hline t: $\quad+497614520714$ & France \\
\hline e: information@karger.de & Librairie Médi-Sciences Sarl \\
\hline w: www.karger.de & $\begin{array}{l}\text { 36, bd de Latour-Maubourg } \\
\text { 75007 Paris }\end{array}$ \\
\hline Japan & France \\
\hline Karger Japan, Inc. & $\mathrm{t}: \quad+33(0) 145514258$ \\
\hline Shiba Daimon Asahi Bldg. 2F & $\mathrm{f:}+33(0) 145560780$ \\
\hline 1-2-23 Shiba Daimon & e: librairie@medi-sciences.fr \\
\hline Minato-ku & w: www.medi-sciences.fr \\
\hline Tokyo 105-0012 & \\
\hline Japan & \\
\hline t: +81364356242 & \\
\hline f: +81364356244 & \\
\hline e: publisher@karger.jp & \\
\hline w: www.karge & \\
\hline
\end{tabular}

Change of Address:

Both old and new address should be sent

to the subscription source.

\section{KARGER}

E-Mail karger@karger.com www.karger.com
(C) 2013 S. Karger AG, Basel

The Journal Home Page is available at: www.karger.com/nen
South East Asia, China and Taiwan Karger Regional Office (Malaysia)

CEO Suite Kuala Lumpur

Quill 7, 27th Floor

Jalan Stesen Sentral 5

KL Sentral

Kuala Lumpur 50470

Malaysia

t: +60327766803

f: +60327766999

e: service@karger.cn; r.chew@karger.cn

Karger China

10th Floor, Twin Towers (East)

B12 Jianguomenwai Avenue

Beijing 100022

China

$\mathrm{t}:+861051235033$

f: +861051235122

e: service@karger.cn; r.chew@karger.cn

w: www.karger.cn

India, Bangladesh, Sri Lanka

Medscience India

Plot No. 17, Yusuf Sarai Market

B.L. Glass Building, 2nd Floor

Sri Aurobindo Marg

New Delhi 110016

India

t: +911146029633

f: +911146029634

c: +919891052128

e: medsci.india@gmail.com 


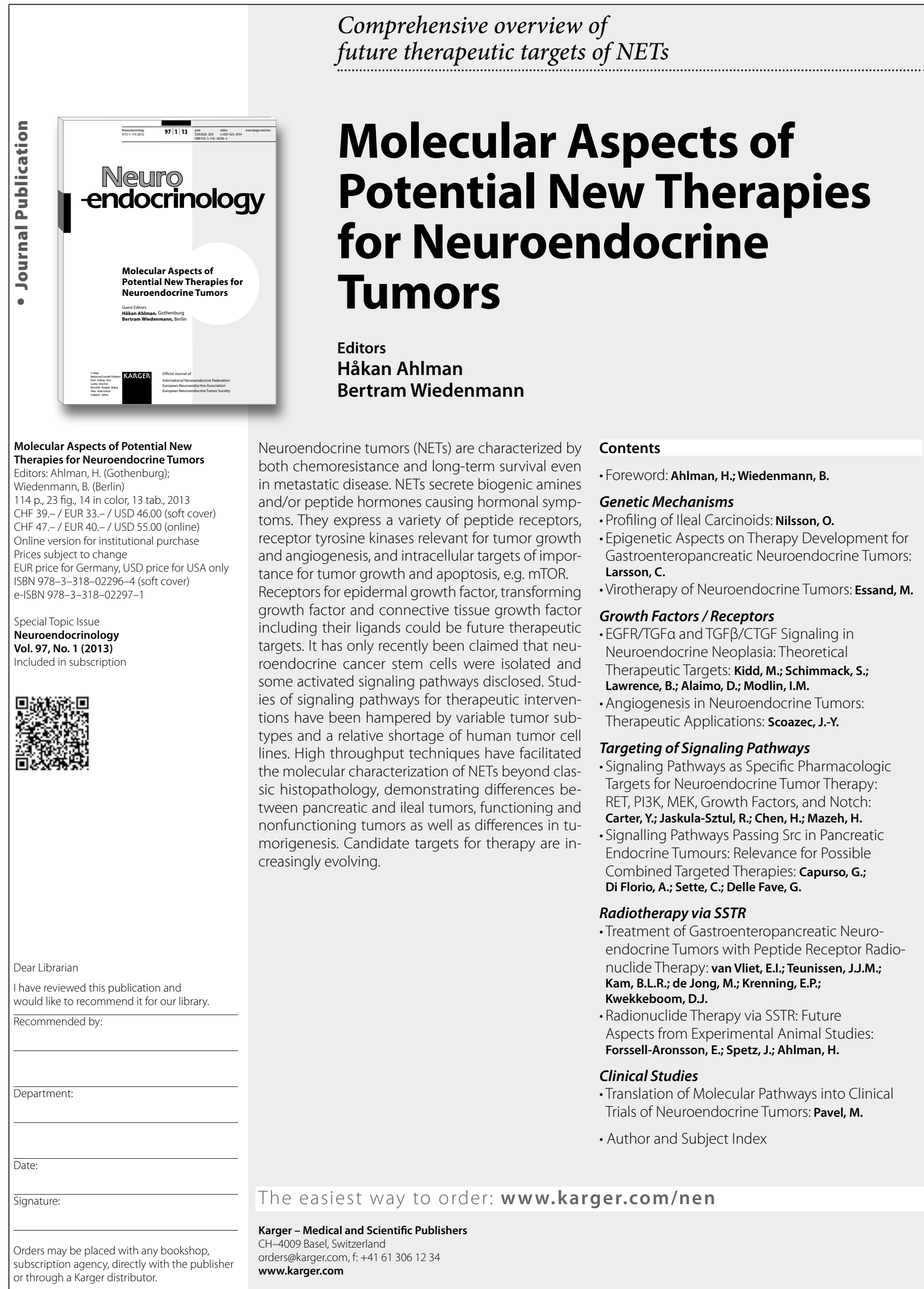




\section{Contents}

See the journal website for contents

KARGER Basel $\bullet$ Freiburg $\cdot$ Paris $\bullet$ London $\bullet$ New York $\cdot$ New Delhi $•$ Bangkok Beijing $\cdot$ Tokyo $\cdot$ Kuala Lumpur $\cdot$ Singapore $\bullet$ Sydney 

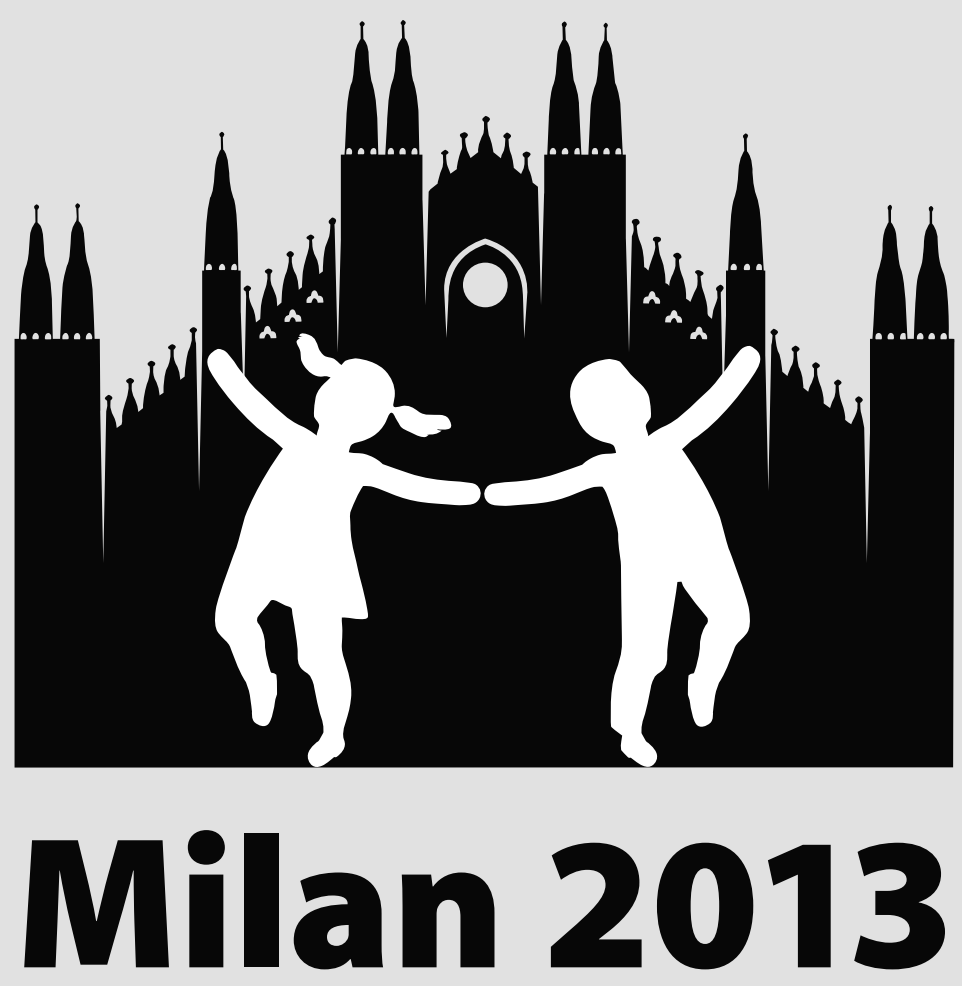
9th Joint Meeting of Paediatric Endocrinology ESPE-PES-APEG-APPES-ASPAE-JSPE-SLEP September 19-22, Milan, Italy

\section{Predictive Medicine to Improve the Care of Children}

www.jointmeeting2013.org 


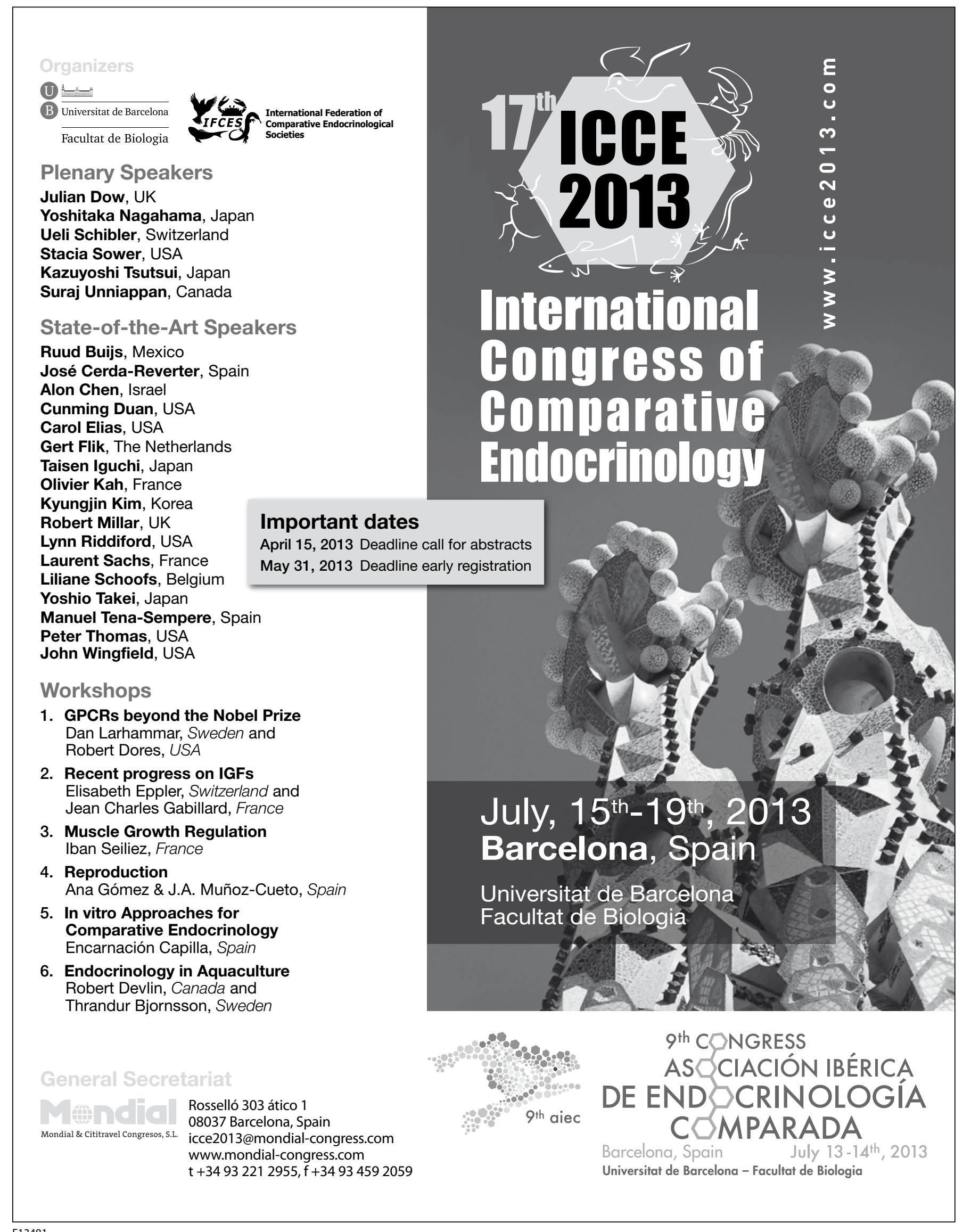




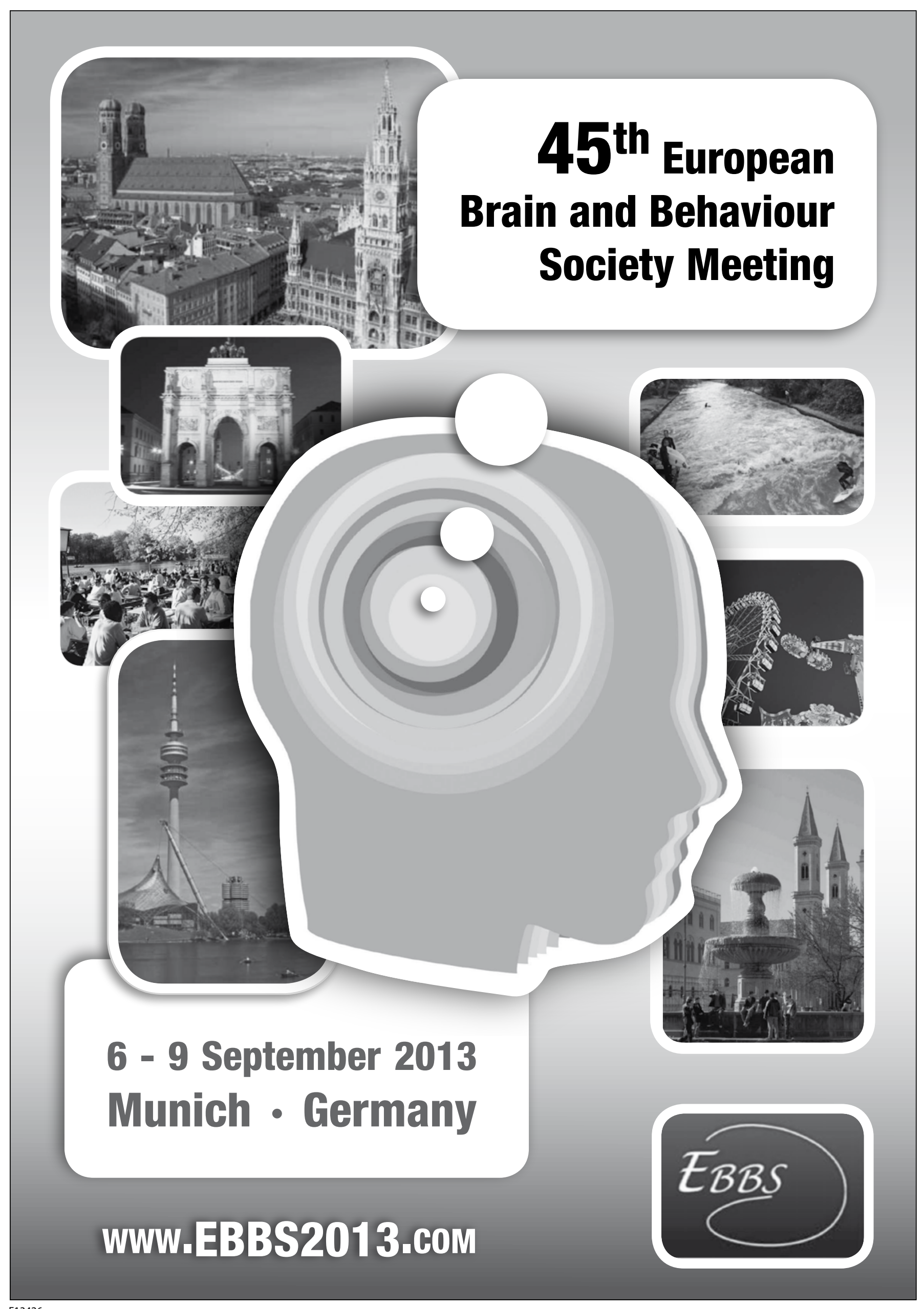




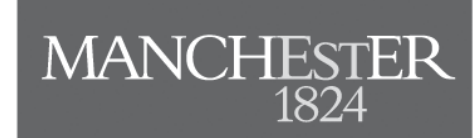

THE UNIVERSITY OF MANCHESTER

\section{BSN}

British

Society for

Neuroendocrinology

\section{The British Society for Neuroendocrinology Annual Meeting 2013}

University of Manchester, Sackville Street Building Sun 7 July - Tue 9 July 2013

Lecture Programme includes:

- Opening Keynote Lecture - Endocrine disorders in children

Prof. Peter Clayton, U. Manchester

- BSN Annual Award Lecture - Biological clocks

Prof. Michael Hastings, U. Cambridge

Symposia Subjects:

- Early Life Programming

- Nuclear Hormone Receptors

- Thermogenesis

In addition:

- Translational Workshop/Debate on Pituitary Tumours

- The Mick Harbuz Young Investigator Prize lecture

- Short oral presentations from submitted abstracts

- Student presentation prizes

The abstract and registration deadlines for the meeting will be May $3^{\text {rd }}, 2013$.

The University of Manchester

Neuroscience

Research Institute

MAHSC

MAM

For more information and details of how to register, visit the BSN website:

www.neuroendo.org.uk

or

- Society for Endocrinology

www.bsn2013.Is.manchester.ac.uk 


\section{New journal}

European

Thyroid Journal

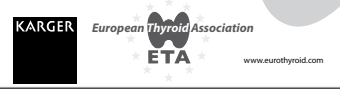

Editor-in-Chief

Wilmar M. Wiersinga,

Amsterdam

Associate Editors

Josef Koehrle, Berlin

(Basic Thyroidology)

Peter Laurberg, Aalborg

(Clinical Thyroidology)

Furio Pacini, Siena

(Thyroid Cancer)

Luca Persani, Milan

(Translational Thyroidology)

\section{Editorial Board}

Maria Alevizaki, Athens

Ana Aranda, Madrid

Rebecca Bahn, Rochester, Minn.

Paul Banga, London

Luigi Bartalena, Varese

Bernadette Biondi, Naples

Anita Boelen, Amsterdam

Georg Brabant, Lubeck

Henning Dralle, Halle

Creswell J. Eastman,

Westmead, N.S.W.

Murat Erdogan, Ankara

Valentin Fadeyev, Moscow

Ulla Feldt-Rasmussen,

Copenhagen

Laszlo Hegedus, Odense

George J. Kahaly, Mainz

Rui Maciel, São Paolo

Ana Luiza Maia, Porto Alegre

Jens Mittag, Stockholm

Ralf Paschke, Leipzig

Simon Pearce,

Newcastle-upon-Tyne

Robin P. Peeters, Rotterdam

Kris Poppe, Brussells

Samuel Refetoff, Chicago, III.

Jacques Samarut, Lyon

Pilar Santisteban, Madrid

YoungKee Shong, Seoul

Johannes Smit, Leiden

Mark Vanderpump, London

Theo Visser, Rotterdam

Paolo Vitti, Pisa

Graham R. Williams, London

Shunichi Yamashita, Nagasaki

Mariastella Zannini, Naples
Call for papers

\section{European \\ Thyroid Journal}

The European Thyroid Journal publishes papers reporting original research in basic, translational and clinical thyroidology. Original contributions cover all aspects of the field, from molecular and cellular biology to immunology and biochemistry, from physiology to pathology, and from pediatric to adult thyroid diseases with a special focus on thyroid cancer. Readers also benefit from reviews by noted experts, which highlight especially active areas of current research. The journal will further publish formal guidelines in the field, produced and endorsed by the European Thyroid Association.

\section{Call for papers}

The editors cordially invite you to submit your research papers to the European Thyroid Journal. Manuscripts written in English can be submitted online. Detailed Online Submission Instructions with a link to the Submission Website are at $\mathbf{w} \mathbf{w} \mathbf{w}$. karger.com/etj. Before submitting your manuscript, you are encouraged to review the detailed guidelines at $\mathbf{w} \mathbf{w} \mathbf{w}$. karger.com/eti_guidelines for specific directions as how to get a manuscript ready for submission.

\section{European Thyroid Journal}

2012: Vol. 1 with 4 issues

Language: English

ISSN 2235-0640

e-ISSN 2235-0802

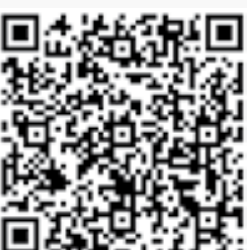

Official Journal of the

European Thyroid Association

KARGER

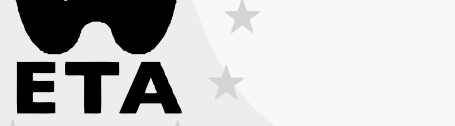


- Neurpo

Original Papers

115 Identification and Analysis of Two Novel Sites of Rat GnRH Receptor Gene Promoter Activity: The Pineal Gland and Retina

Schang, A.-L.; Bleux, C.; Chenut, M.-C.; Ngô-Muller, V.; Quérat, B.; Jeanny, J.-C.; Counis, R.; Cohen-Tannoudji, J.; Laverrière, J.-N. (Paris)

132 Central Dopaminergic Activity Influences Metabolic Parameters in Healthy Men Brunerova, L.; Potockova, J.; Horacek, J.; Suchy, J.; Andel, M. (Prague)

139 Increased Prevalence of Anxiety-Associated Personality Traits in Patients with Cushing's Disease: A Cross-Sectional Study

Dimopoulou, C.; Ising, M.; Pfister, H.; Schopohl, J.; Stalla, G.K.; Sievers, C. (Munich)

146 Aging and Diets Regulate the Rat Anterior Pituitary and Hypothalamic Transcriptome

Bédard, K.; Bédard, J.; Rocheleau, G.; Ferland, G.; Gaudreau, P. (Montreal, Qué.)

160 Receptor Subtypes and Signal Transduction Mechanisms Contributing to the Estrogenic Attenuation of Cannabinoid-Induced Changes in Energy Homeostasis Washburn, N.; Borgquist, A.; Wang, K.; Jeffery, G.S. (Pomona, Calif.); Kelly, M.J.

(Portland, Oreg.); Wagner, E.J. (Pomona, Calif.)

176 Intranasal Insulin Modulates Intrinsic Reward and Prefrontal Circuitry of the Human Brain in Lean Women

Kullmann, S.; Frank, S.; Heni, M.; Ketterer, C.; Veit, R.; Häring, H.-U.; Fritsche, A. (Tübingen); Preissl, H. (Tübingen/Little Rock, Ark.)

183 Synergistic Effect of Pasireotide and Teriflunomide in Carcinoids in vitro Somnay, Y.; Chen, H.; Kunnimalaiyaan, M. (Madison, Wisc.)

Rapid Communication

193 Kisspeptin Restores Pulsatile LH Secretion in Patients with Neurokinin B Signaling Deficiencies: Physiological, Pathophysiological and Therapeutic Implications

Young, J. (Le Kremlin-Bicêtre); George, J.T.; Tello, J.A. (Edinburgh); Francou, B.; Bouligand, J.; Guiochon-Mantel, A.; Brailly-Tabard, S. (Le Kremlin-Bicêtre); Anderson, R.A. (Edinburgh); Millar, R.P. (Edinburgh/Pretoria/Cape Town) 